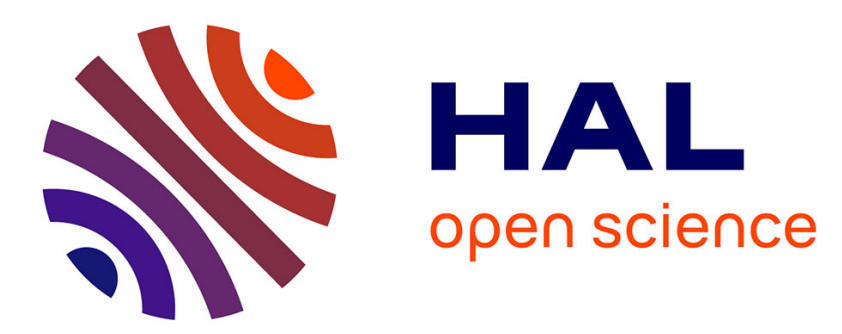

\title{
Agroecological weed control using a functional approach: a review of cropping systems diversity
}

Sabrina Gaba, Guillaume Fried, Elena Kazakou, Bruno Chauvel, Marie-Laure Navas

\section{- To cite this version:}

Sabrina Gaba, Guillaume Fried, Elena Kazakou, Bruno Chauvel, Marie-Laure Navas. Agroecological weed control using a functional approach: a review of cropping systems diversity. Agronomy for Sustainable Development, 2014, 34 (1), pp.103-119. 10.1007/s13593-013-0166-5 . hal-01234789

\author{
HAL Id: hal-01234789 \\ https://hal.science/hal-01234789
}

Submitted on 27 Nov 2015

HAL is a multi-disciplinary open access archive for the deposit and dissemination of scientific research documents, whether they are published or not. The documents may come from teaching and research institutions in France or abroad, or from public or private research centers.
L'archive ouverte pluridisciplinaire HAL, est destinée au dépôt et à la diffusion de documents scientifiques de niveau recherche, publiés ou non, émanant des établissements d'enseignement et de recherche français ou étrangers, des laboratoires publics ou privés. 


\title{
Agroecological weed control using a functional approach: a review of cropping systems diversity
}

\author{
Sabrina Gaba • Guillaume Fried • Elena Kazakou • \\ Bruno Chauvel • Marie-Laure Navas
}

Accepted: 28 June 2013 / Published online: 1 August 2013

(C) INRA and Springer-Verlag France 2013

\begin{abstract}
Agriculture since the 1950s has shown pronounced trends toward specialisation and intensification. Intensive measures have been taken for crop protection against pests through the widespread use of chemical pesticides in order to reduce the loss of agriculture yield. Although crop protection practices have reduced the overall potential losses of $50 \%$ to actual losses of about $30 \%$, crop losses due to pests still vary from 14 to $35 \%$ according to the country. Moreover, consequences of this intensive agriculture are now well known with an important increase of atmospheric $\mathrm{CO}_{2}$ concentrations, water pollution and biodiversity loss. Current challenge is thus to design alternative sustainable cropping systems which maintain food production while reducing externalities. Application of ecological principles to agroecosystems has been proposed for that purpose. Nonetheless, it is difficult since crop systems are characterised by frequent and high disturbances, high nutrient input and high pressure of human activities. Here, we review the current knowledge in weed science and functional ecology and propose a conceptual framework to analyse weed community assembly in arable fields. Cropping systems are highly variable in their combination of agricultural techniques. We designed a trait-based approach of functional diversity (1) to establish a comparative description of the
\end{abstract}

S. Gaba $(\bowtie) \cdot$ B. Chauvel

INRA, UMR1347 Agroécologie, 17 rue Sully,

F-21065 Dijon Cedex, France

e-mail: sabrina.gaba@dijon.inra.fr

G. Fried

Anses, Laboratoire de la Santé des Végétaux, Unité Entomologie et Plantes invasives, Campus International de Baillarguet,

34988 Montferrier-sur-Lez Cedex, France

E. Kazakou $\cdot$ M.-L. Navas

Montpellier SupAgro, UMR 5175 Centre d'Ecologie Fonctionnelle et Evolutive, F-34293 Montpellier Cedex 52, France environmental gradients created by cropping systems and (2) to characterise the response of weeds to environmental gradients. We categorise the effects of cropping systems on the environment into disturbance and resource gradients. Disturbances induced by actual and previous agricultural practices are split into physical and chemical components, whose regime are defined by disturbance timing and frequency. Resource availability in arable fields is described by the value of effect traits of crops, such as plant height, that are related to their use of resources. Finally, we provide a list of relevant response traits of weeds to each component of the two gradients.

Keywords Response traits · Gradients · Disturbances · Resources $\cdot$ Biotic interaction

Contents

1. Introduction. . . . . . . . . . . . . . . . . . . 1

2. Resource and disturbance gradients in arable fields... 3

2.1. Local conditions. ..................... 4

2.2. Resource gradients.................... 4

2.3. Disturbance gradients. ................... 5

2.3.1. Legacy from past disturbance regimes. . . . . . . 6

2.3.2. Regime of disturbances. ...............6 6

2.3.3. Types of disturbances. ................. 8

3. Weed response traits to management practices...... 9

3.1. Functional types..................... 10

3.2. LHS framework. ..................... 10

3.3. Specific response traits................... 11

4. Conclusions and perspectives............... 12

\section{Introduction}

The intensive use of agroecosystem during the last decades to provide products for consumption and processing toward 
specialisation and intensification in use of purchased seed, fertiliser, pesticides and fuel, has resulted in a great reduction of biodiversity (Robinson and Sutherland 2002) and negative environmental impacts such as water pollution or nitrogen excess (Tilman et al. 2011; Cardinale et al. 2011). In particular, heavy agricultural reliance on synthetic chemical pesticides for crop protection against pests has been recognised for water pollution (IFEN 2007) and biodiversity loss (Stoate et al. 2001). Despite the efficiency of chemical pesticides to reduce the overall potential crop production losses of $50 \%$ to actual losses of about $30 \%$, crop loss induce by pest still vary from 14 to $35 \%$ according to the country (Oerke 2006). Thus, contemporary agriculture now faces conflicting challenges due to the need of increasing or expanding production while simultaneously reducing environmental impacts. According to agroecology principles, by understanding ecological processes, agroecosystems can be manipulated to improve production efficiency and sustainability, with fewer negative environmental or social impacts and lower use of external inputs (Gliessman 2006; Altieri 1989; Altieri and Rosset 1995; Wezel et al. 2009). Among others, a major challenge is to design new management rules to regulate pest communities based on population dynamic predictions and biotic regulations using concepts and theories from the ecology of more natural ecosystem.

However, agroecosystems contrast with natural ecosystems and other more diverse man-managed systems from several points. First, agroecosystems constitute outstanding environments with intense and frequent disturbances. There are only few other environments that are subjected to a similar disturbance regime: for example, river banks subjected to flood regimes (Bornette et al. 2008), areas subjected to fire (Bossuyt and Honnay 2008) or areas disturbed by animals' activity (Lavorel et al. 1998). Moreover, the frequencies and intensities of disturbances obey to human decision rules, hence environmental variability is highly unpredictable for species which are characterised by fast dynamics and adaptive capacity to changing conditions. Second, agroecosystems are artificially nutrient-rich ecosystems because of the significant resource inputs from fertilisation and irrigation, in order to ensure an optimal growth and biomass production of crop plants. As a result, arable fields are high productive environments, and during certain periods, resource availability exceeds crop uptake, allowing the growth of other plant species. Third, agroecosystems, and especially arable fields, are generally dominated by one species, the crop. As a consequence, the 'dominance-diversity' profil (Whittaker 1965; Grime 1998) is largely deviated with important differences between the number of crop plants and the number of plants of the most abundant weed species. Such deviation may have important consequences on ecosystem functioning, because the functional structure of the community as a whole is mostly related to one species. Finally, agroecosystems are very original systems because few environments are both highly disturbed and nutrient rich compared with other ecosystem. Moreover, nutrient amount is regulated in order to favour crop production and thus varies from crop to crop and among fields. Given all these specific features, agroecosystems represent an original system to investigate structural properties of community dynamics or species assembly.

Weeds are a major problem in crop production because of their competition for resources with crops, with a potential crop loss up to $34 \%$ each year (Oerke 2006). In parallel, weeds have recently been acknowledged for functionalities to other taxa in the agroecosystem (Marshall et al. 2003; Nicholls and Altieri 2013; Petit et al. 2011), being at the basis of trophic chain (Fig. 1). Weeds are facing intense and frequent disturbances of different natures such as soil tillage, herbicide spray and crop harvest. This partly explains why weed seeds have the ability to survive in the soil remaining dormant for a number of years, up to 30 years (Roberts and Feast 1973). The composition, structure and dynamic of the seed bank result from the temporal change in crops and associated crop management practices (Dessaint et al. 1990; Clements et al. 1996), hence weed community reflects the past cropping history and diversity at a site (Ulber et al. 2009; Smith et al. 2010). However, most of the studies on weed communities focus on the effect of one factor on weeds, e.g. herbicides (Manalil et al. 2011) or different soil tillage systems (Albrecht and Auerswald 2009) but rarely considered management practices as a whole (see Ryan et al. 2010 for exception). Moreover, management practices vary from farm to farm and with pedoclimatic conditions (Fried et al. 2008). Therefore, general principles on the response of weed species to management practices and environmental conditions remain to be established. To address this issue, weed research needs to move from a too narrow perspective focusing on specific problems in crop production due to weeds (e.g. yield loss or toxicity) to an understanding of the processes underlying species assembly, i.e. the processes related to the coexistence of species, the recognition of groups of species that respond similarly to a set of environmental conditions or management practices or that similarly affect the ecosystem (Booth and Swanton 2002; Weiher et al. 2011; Navas 2012)

The aim of the present paper is to propose a standardised characterisation of the environmental conditions created by cropping systems, defined as the crops and crop sequences and the management techniques used on a particular field over a period of years to investigate the response of weed species and the structure of communities they form among comparable conditions. Our assumption is that the understanding of both occurrence and abundance of weeds along environmental gradients depending on agricultural practices would improve our ability to predict weed dynamics to 
Fig. 1 Weeds provide shelter and food for various taxa of the agroecosystems such as those illustrated on these photographs, either beneficial species for pollination services or crop pests (Fried, personal communication). Therefore, the wise agroecological management of weeds should keep weed species of functional interest for regulation, e.g. biocontrol or trophic resources and cultural services

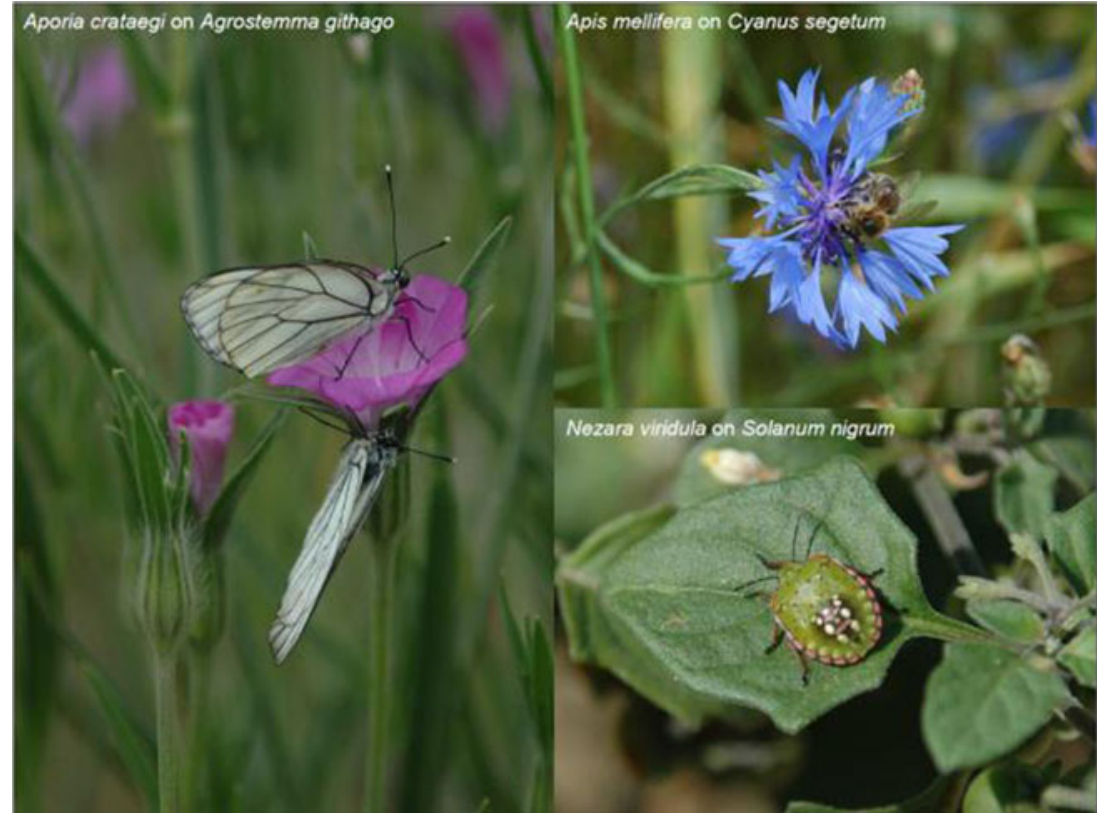

further design sustainable management measures. We propose to characterise the species response to gradients using traits instead of identifying patterns of species diversity for two reasons : (1) different combinations of resource and disturbance levels are known to lead to similar patterns in species diversity (Huston 1979) whereas combination of traits responding to one or other gradients are different (Garnier and Navas 2011), (2) characterising the response to gradients of traits that are mechanistically sound should allow to predict the structure of communities in a larger range of environmental conditions (Shipley et al. 2006; McGill et al. 2006). Here, we first propose a conceptual framework to characterise the cropping systems on the basis of properties that affect plants performance, i.e. resource and disturbance levels. Description of gradients is an excellent way to do this (Austin 1980; Garnier et al. 2007) and could provide a template to detect how weed respond to cropping systems. Second, we identify weed traits responding to these gradients. The response-effect framework proposed by (Lavorel and Garnier 2002) and (Suding et al. 2008) is increasingly used to investigate species assembly patterns through the identification of response traits that show a consistent response to a particular environmental gradient and of effect traits that modulate one or several ecosystem functions. The utility of the trait-based approach for characterising weed response to management practices has been clearly established in weed science (Lososvà et al. 2006; Storkey 2006; Fried et al. 2009; Gunton et al. 2011; Fried et al. 2012) but without leading yet to predictions. Therefore, we propose to identify which traits of weeds respond to standardised resource or disturbance gradients characterising the cropping systems. Finally, we discuss the application of our framework given the specific properties of agroecosystem, including how it could be used to detect the effect of weeds on agroecosystem functioning.

\section{Resource and disturbance gradients in arable fields}

The description of environmental gradients has been a major concern in community ecology because of the clear impact of environmental gradients on species distribution: see earlier references in Austin (1980) and Garnier et al. (2007).

Environmental gradients are usually spited into several factors or characteristics that impact plant traits. Complex gradients, e.g. gradients of altitude or post-cultural succession, are usually described by the variable used to design plant records, which is rarely the one acting directly on plant functioning (Austin and Smith 1989) and which limits generalisation and comparison among sites. Therefore, the gradients are often split into resource and disturbance components (Grime 1979) in order to compare highly contrasted environmental situations, including situations with disturbances of very different types. Translating cropping systems into environmental gradients is challenging because of the complexity of the system and the dependency of management practices on local conditions, crop types and socio-economic constraints. Following Garnier et al. (2007), we suggest splitting this complex system into three main components: (1) the local conditions characterising the site independently of actual land use, such as climatic, soil or history conditions, (2) resource availability and (3) disturbance levels that directly depend on management and crop type. 


\subsection{Local conditions}

Climate and soil conditions and land-use history constrain the cropping system and management practices; for example, the effects of frosts during winter or low $\mathrm{pH}$ soils cannot be quickly compensated for by management and highly constrain management options. Hence, these environmental drivers have significant direct and indirect effects on weed species distribution in interaction with management practices (Navas 2012). Their influence has been especially documented at large spatial scale by national and regional comparisons (e.g. Fried et al. 2008). At that scale, the environmental factors that significantly influence weed communities are soil $\mathrm{pH}$ and texture, site rainfall and temperature (Maillet 1981; Fried et al. 2008; Cirujeda et al. 2011). History of land use can also influence today species communities (e.g. Roman land use and communities established in forests; (Sciama et al. 2009), yet its effects are often merged into soil effects. Climatic conditions can be described by a large number of variables, most of them being redundant, e.g. temperature and solar radiation (Pakeman et al. 2009). Therefore, synthetic indices based on combination of variables such as aridity or rainfall effectiveness indices or linear combination of variables in multivariate analyses can be relevant (Garnier et al. 2007) with the latter being useful also for including categories of soils that cannot be easily differentiated by continuous variables.

\subsection{Resource gradients}

In arable fields, the resource gradients can be described by indices related to the amount of resources available for other plant species than the crop. This is not an easy task because this requires getting synthetic indices indicating the global productivity of the site and the interaction milieu (sensu (McGill et al. 2006) detected by weeds. It is highly relevant to consider this two-level characterisation because for a given crop type, the weed species that can potentially establish in high productive conditions are most probably different than the ones that can potentially establish in lowproductive conditions (Cousens and Mortimer 1995; Moss et al. 2004).

The potential productivity at a site, defined as the favourability of environmental conditions for plant growth, although dictated by local conditions, such as bedrock, soil and climatic properties, is strongly modulated by fertilisation and/or irrigation and by crop demand according to variety and sowing density. Most of the methods used to evaluate site potential productivity are based on soil variables. However, these variables had failed in detecting soil fertility. Indeed, soil nutrient or water contents are not proxies of nutrient or water availability for plants because they strongly interact with soil characteristics such as texture, $\mathrm{pH}$ and organic matter content. Another approach formerly developed for grasslands is to calculate nutrient indices that depict plant nutrient status by comparing the actual resource concentration of a community to a reference obtained for monocultures established under optimal growth conditions (see references in Garnier et al. 2007). However, the lack of references for other communities than those dominated by grasses (but see Cruz et al. 2006) for mixed grasslands, constrains the generalisation of these indices to other communities. Moreover, there are experimental constraints on getting a synthetic index of crop water status. Current procedures require regular and time-consuming estimates of soil water content (Boulant et al. 2008; Gross et al. 2008) and/or of crop hydrological parameters and leaf area indices (Larcher 2003). To summarise, the level of potential productivity at a site can be assessed by synthetic indices which reveal the nutrient and water status of species. However, their generalisation to a larger set of species requires further methodological work.

For all these reasons, we recommend another approach of resource gradients occurring in crop systems by characterising the effect traits of crop plants that are directly related to resource use, according to the trait-based framework proposed by Navas and Violle (2009) and Violle et al. (2009a). The framework describes a cascade of relationships between plant traits, resource depletion and competitive outcome (Fig. 2). The effect traits of the dominant species grown in monoculture (such as the crop) are used to quantify the amount of resources available for the other plants in the community (such as weeds) to which the latter plants respond by changes in values of response traits.

Competition for light is considered to be the primary cause modulating high-density community structure (Weiner 1988, 1990). Therefore, traits related to light interception are accurate candidates for assessing competition for light. Light interception by crop plants is generally highly efficient because of their large stature favoured by local productive conditions. Furthermore, crop plants have a competitive advantage over weeds in the run for light because they are theoretically established earlier and favoured by management practices such as high seed density (Weiner et al. 2010). As a consequence, crop plants are generally taller than weeds in the early stage, which may favour asymmetric or partial size asymmetric competition for light (Schwinning 1996). Violle et al. (2009a) found that the measurement of plant height at canopy closure depicted light depletion over the growing season from plant establishment to seed production under the cover of 18 monocultures differing in growth form and phenology. Moreover, this instantaneous measurement was also a proxy of water shortage under monoculture cover over the growing season because of the allometric relationship between plant height and root depth. The relationship between plant height and light capture is a very 
Fig. 2 Trait-based framework modified from Violle et al. (2009a). The effect traits of the crop modify the amount of resources available for the weeds inducing changes in values of response traits

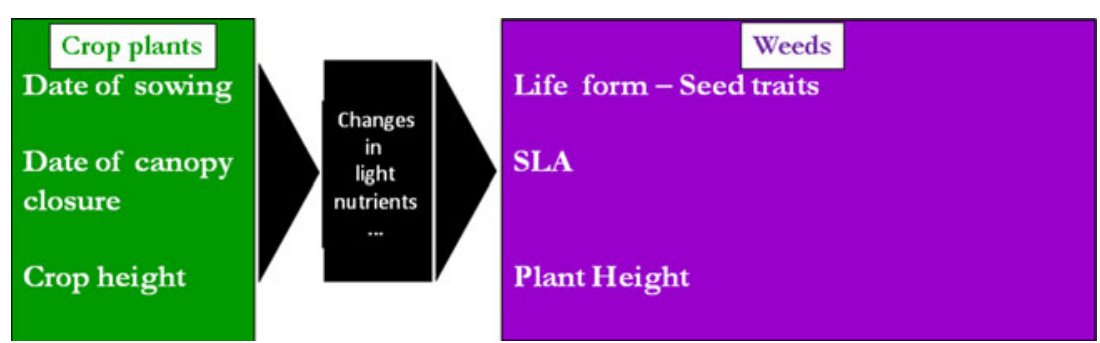

well-known relationship largely used for plant growth modelling (see references in Navas and Violle 2009 and Violle et al. 2009a); however, the novelty of the study by Violle et al. (2009a) was to extend this result to inter-specific comparisons and to demonstrate that a unique measure of height over the season is a proxy of year-round use of resources. However, because the measurement of plant height at canopy closure might be difficult in large comparative experiments as a consequence of differences in phenology among crops, this trait can be approximated by plant maximal height, a trait classically used to assess competitive ability for light (Westoby et al. 2002) and tolerance to environmental constraints (Cornelissen et al. 2003). Similarly, in cultivated stands where soil cover is incomplete (e.g. root crops...), plant height might be replaced by plant lateral spread, another sizerelated trait that is a proxy of plant competitive ability (Navas and Moreau-Richard 2005; Gross et al. 2007). Although easy to measure, plant maximal height is only slightly correlated to the use of resource over the season (Violle et al. 2007) and the same should be true for maximal lateral spread (Gross et al. 2007). Therefore, other traits corresponding to the period of time during which resources are used should be also considered (Navas and Violle 2009). Crop sowing date and onset of flowering are relevant candidates since they limit the two ends of the period of resource use by the crop, are related to plant maximal height (Sun and Frelich 2011) and are major traits determining weed species distribution (Gunton et al. 2011).

To summarise, we propose to describe the resource gradients in arable field by crop traits i.e. plant height and phenology that directly affect the resource pool available for weeds. Moreover, the values of crop traits reflect cropping systems and depict local resource availability (Table 1). A high sowing density increases the competitive advantage of crop plants over weeds (Weiner 1986) through changes in crop height (Xiao et al. 2006) and date of canopy closure (Weiner et al. 2010). Row spacing influences the relative impact of intra-specific (occurring on a row among crop plants) versus inter-specific relations among crop and weeds, through plant height distribution (Benjamin et al. 1985; Weiner et al. 2010).

\subsection{Disturbance gradients}

Disturbance is here defined as “....any relatively discrete event in time that disrupts ecosystem, community, or population structure and changes resources, substrate availability, or the physical environment" (White and Pickett 1985). The disturbance regime in arable ecosystems is cyclic in relation to the temporal succession of different types of disturbances (Kropáč et al. 1971). Several components are commonly used to describe the regime of disturbances (Sousa 1984; Garnier et al. 2007; White and Pickett 1985; Kühner and Kleyer 2008). Although we are aware of the effect of disturbances at the landscape scale, the disturbed area here is the field. We propose to describe the cropping system into three parts: legacy from past disturbance regimes, regime of disturbance and types of disturbances. The description of the legacy from past disturbance regimes gives insights into the initial state of the weed flora of an arable field since weed
Table 1 Description of management practices that influence crop effect traits, therefore impacting the level of resources available for weeds

The most impacted resource by each cropping system is set in italics. See text for references

\begin{tabular}{lll}
\hline Management practices & Crop functional traits/characteristics & Resource \\
\hline Sowing density & $\begin{array}{l}\text { Plant height or plant lateral spread (root crops) } \\
\text { Date of canopy closure }\end{array}$ & Light, nutrients, and water \\
Sowing date & $\begin{array}{l}\text { Plant height or plant lateral spread (root crops) } \\
\text { Date of canopy closure }\end{array}$ & Light, nutrients, and water \\
Row spacing & $\begin{array}{l}\text { Plant height or plant lateral spread (root crops) } \\
\text { Date of canopy closure } \\
\text { Fertilisation }\end{array}$ & Light, nutrients, and water \\
& $\begin{array}{l}\text { Plant growth rate plant height or plant lateral } \\
\text { spread (root crops) }\end{array}$ & Nutrients and light \\
Irrigation & $\begin{array}{l}\text { Plant phenology } \\
\text { spread (root crops) }\end{array}$ & Water and light \\
& $\begin{array}{l}\text { Plant phenology } \\
\text { lant }\end{array}$ & \\
\hline
\end{tabular}


flora composition and structure are partially related to previous crop sequence (Ball 1992; Chikowo et al. 2009). The regime of disturbance is described by four temporal items: the onset, the frequency, the return interval and the end of the disturbances. The type of disturbances refers either to the physical disturbances that include soil tillage and mechanical weed control or to chemical disturbances such as herbicide treatments. The different levels of these two types are identified by the magnitude of the disturbances, i.e. the intensity which is a measure of the strength of the disturbance and the severity which is a measure of the damage caused by the disturbance. These components are described below, with illustration of different levels by examples found in Northern Europe (Table 2).

\subsubsection{Legacy from past disturbance regimes}

The legacy from past disturbance regimes refers to the regimes of disturbances induced by the crops cultivated at a site the preceding years. A crop sequence is defined as a succession of annual crops with or without intercrops (catch crops). In a field, the current weed community is the expression of the seed bank which does not only include seeds produced the year before (it has been shown that the preceding crop has a major effect on the composition of the emerged weed flora; Fried et al. 2008) but also seeds produced the previous years since seed longevity of many weed species easily exceed one decade in the soil (Lewis 1973). Although of crucial importance in understanding the current weed flora, the cropping history variables that are relevant for this investigation and hence should be detailed, are still debated. Following Bohan et al. (2011), we propose to detail the field history into broader crop management classes depending on the seasons of sowing, the practice with the largest impact on weed communities and crop type including the main weed target for herbicide application (see Table 3 for a detailed description). The past disturbance regimes can thus be ranked based on the degree of variation in the crop sequence and associated management practices, by computing the mean and the coefficient of variation in the transitions between successive crops in a crop sequence (see Fig. 3 for examples), as described thereafter.

The transition between two successive crops can be classified into five levels. The level 1 (i.e. c.v. equals 0 ) corresponds to a monoculture which refers to the successive cultivation of a single crop species (e.g. a crop sequence of maize) and therefore results in nearly similar and regular inter-year disturbances i.e. sowing dates, herbicides in terms of treatment dates and modes of action. This level also refers to situations close to a monoculture where crops are of similar type, e.g. winter barley and winter wheat, sorghum and maize, have close sowing dates and have herbicides belonging to the same chemical families. Level 2 corresponds to a pattern of two crops with similar sowing dates but of different crop type, while level 3 denotes patterns of two crops of similar type (and similar herbicide targets) but with different sowing date. Level 4 indicates large differences between the two crops of the patterns which differ in sowing dates, crop type and associated herbicides. Level 5 represents the transition between an annual crop and a catch crop. Such transitions occur in crop sequences with inter-crop cultivated for environmental purposes, i.e. decrease of fertiliser uses. Finally, level 6 refers to a crop sequence with one or more perennial crops which have been shown to highly affect weed communities trajectories, mainly due to change in disturbance regimes such as shifting from ploughing to mowing de Gournay (1963); Meiss et al. 2010).

\subsubsection{Regime of disturbances}

To move from the disturbance event to the disturbance regime that is needed to describe a gradient, we propose to include the temporal characteristics of agricultural practices such as the period of occurrence limited by the onset and end of disturbances, frequency and the return interval of disturbances over the crop growth period. The duration of disturbances can be neglected because of very short value in cropping systems.

In arable fields, the onset of disturbance corresponds to the sowing date of the crop, a major factor shaping weed community composition by favouring species able to germinate and emerge at the same time than the crop species (Gunton et al. 2011; Smith 2006; Milberg et al. 2001). Three groups of annual crops can be distinguished on the basis of sowing date: winter crops that are sown from late summer (winter oilseed rape) to autumn (winter cereals), crops sown in late winter (spring cereals and spring pea) and summer crops that are established during spring (sugar beet, potatoes, maize, sunflower, soybean and sorghum). We propose to encode the sowing date in Julian weeks to take into account the differences in date that occur within groups and among sites and years.

The end of disturbance corresponds to the date of the management that ends the period during which weeds can complete their life cycle. Most often, this date corresponds to crop harvest, characterised by crop plant reaping and stubble grounding. Otherwise, the end of disturbance corresponds to stubble ploughing when this practice is significantly delayed in time relative to harvest. As for the onset of disturbances, we propose to encode the end of disturbance in Julian weeks. The period of time between the onset and the end of disturbances corresponds to the crop growth period that limits the period when annual weeds must establish and complete their life cycle.

The frequency of disturbance is the number of disturbances per unit time. We propose to use the crop growth 
Table 2 Seven parameters are used to describe the disturbance regime and types of disturbance that characterise a cropping system

\begin{tabular}{|c|c|c|c|c|}
\hline $\begin{array}{l}\text { Category of } \\
\text { parameter }\end{array}$ & Parameter & Levels/unit & Description & Examples or comments \\
\hline \multirow[t]{7}{*}{ History } & \multirow{7}{*}{$\begin{array}{l}\text { Legacy from past } \\
\text { disturbance } \\
\text { regimes }\end{array}$} & 1 & -Same crop as actual & Monoculture of maize \\
\hline & & & $\begin{array}{l}\text {-Different crop species but similar crop types } \\
\text { (and herbicides target) and sowing date }\end{array}$ & $\begin{array}{l}\text { Winter wheat after winter barley } \\
\text { and sorghum after maize }\end{array}$ \\
\hline & & 2 & $\begin{array}{l}\text { Different crop types (with different herbicides } \\
\text { target) but similar sowing dates }\end{array}$ & $\begin{array}{l}\text { Winter wheat after winter oilseed } \\
\text { rape and sunflower after maize }\end{array}$ \\
\hline & & 3 & $\begin{array}{l}\text { Different sowing dates but similar crop types } \\
\text { (and similar herbicides target) }\end{array}$ & Maize after winter wheat \\
\hline & & 4 & $\begin{array}{l}\text { Different sowing dates and different crop types } \\
\text { (with different herbicides target) }\end{array}$ & $\begin{array}{l}\text { Maize after oilseed rape and winter } \\
\text { wheat after sunflower }\end{array}$ \\
\hline & & 5 & Catch crop after an annual crop & $\begin{array}{l}\text { Catch plants cultivated for } \\
\text { environmental purpose }\end{array}$ \\
\hline & & 6 & $\begin{array}{l}\text { Perennial forage crops (which imply different } \\
\text { disturbance regime) }\end{array}$ & Winter wheat after lucerne or clover \\
\hline
\end{tabular}

Regime of disturbance Onset of disturbance Julian weeks Date of soil preparation for crop sowing

End of disturbance Julian weeks Date of harvest (or stubble ploughing)

Frequency $\quad \mathrm{Nb}^{*} \mathrm{Time}^{-1} \quad$ Number of disturbances per unit of time

Return interval days Average period of time separating two successive disturbances

\begin{tabular}{|c|c|c|c|}
\hline \multirow{12}{*}{ Types of disturbance } & \multirow{7}{*}{$\begin{array}{l}\text { Chemical } \\
\text { disturbances }\end{array}$} & 0 & No herbicide \\
\hline & & 1 & $\begin{array}{l}\text { Selective broadleaf or grass herbicides } \\
\text { of }<50 \% \text { of the recommended dose }\end{array}$ \\
\hline & & 2 & $\begin{array}{l}\text { Selective broadleaf or grass herbicides } \\
\text { of }>50 \% \text { of the recommended dose }\end{array}$ \\
\hline & & 3 & $\begin{array}{l}\text { Broad-spectrum herbicides of }<50 \% \\
\text { of the recommended dose }\end{array}$ \\
\hline & & 4 & $\begin{array}{l}\text { Broad-spectrum herbicides of }>50 \% \\
\text { of the recommended dose }\end{array}$ \\
\hline & & 5 & $\begin{array}{l}\text { Non-selective herbicides of }<50 \% \\
\text { of the recommended dose }\end{array}$ \\
\hline & & 6 & $\begin{array}{l}\text { Non-selective herbicides of }>50 \% \\
\text { of the recommended dose }\end{array}$ \\
\hline & \multirow{5}{*}{$\begin{array}{l}\text { Physical } \\
\quad \text { disturbances }\end{array}$} & 0 & No tillage \\
\hline & & 1 & $\begin{array}{l}\text { Mechanical weeding or minimum tillage, } \\
\text { depth of soil disturbance at }<5-10 \mathrm{~cm} \text {, } \\
\text { and no soil inversion }\end{array}$ \\
\hline & & 2 & $\begin{array}{l}\text { Mechanical weeding or reduced tillage, } \\
\text { depth of soil disturbance at }>10 \mathrm{~cm}, \\
\text { and no soil inversion }\end{array}$ \\
\hline & & 3 & $\begin{array}{l}\text { Conventional tillage with soil inversion and } \\
\text { depth of soil disturbance at }<25 \mathrm{~cm} \\
\text { Harvest of root crops }\end{array}$ \\
\hline & & 4 & $\begin{array}{l}\text { Conventional tillage with soil inversion } \\
\text { depth of soil disturbance at }>25 \mathrm{~cm}\end{array}$ \\
\hline
\end{tabular}

The duration varies between spring crops (about 16 weeks) and winter crops (36 weeks)

The crop growth period is used as unit of time

All disturbance events are considered

For example, organic farming systems

Synthetic auxin (2.4D) ACCase inhibitors (fenoxaprop-P-ethyl)

ALS inhibitors (sulfonylureas, nicosulfuron etc.)

Glycine (glyphosate)

Brushes $(1-2 \mathrm{~cm})$, rotary hoe $(5 \mathrm{~cm}$, and ; weeder harrow $(2-3 \mathrm{~cm})$

Cultivator

Mouldboard plough

Mouldboard plough

Categorical parameters include different items that are numbered. Units of continuous parameters are given. Crop types are designed according to taxonomic position, sowing date and herbicide application (see Table 3). See text for more details on rationales of categories

period as unit time. The rationale behind this choice is to select a period of time relative to the life span and growth rates of weeds to allow comparison among ecosystems and the detection of general patterns (White and Jentsch 2001).
The return interval of the disturbance is calculated as the average period of time separating two successive disturbances, whatever their types, over the crop growth period: a given number of disturbances can be either spread over the whole 
Table 3 Classification of crop types

\begin{tabular}{ll}
\hline $\begin{array}{c}\text { Taxonomic } \\
\text { classification } \\
\text { and growth form }\end{array}$ & $\begin{array}{c}\text { 1. Annual cereals, i.e. Avena sativa, Hordeum } \\
\text { vulgare, Secale cereale, Sorghum bicolour, } \\
\text { Triticum aestivum, Triticum durum, Zea mays, } \\
\text { and } \times \text { Triticosecale }\end{array}$ \\
2. Annual legumes, i.e. Glycine max, Pisum \\
sativum, Vicia faba \\
3. Root crops, i.e. Beta vulgaris and Solanum \\
tuberosum \\
4. Oleaginous, i.e. Brassica napus and \\
Helianthus annuus \\
5. Perennial forage species, i.e. Lolium perenne, \\
Medicago sativa, and Trifolium pratense \\
1. Autumn and winter crops: H. vulgare, \\
S. cereale, T. aestivum, B. napus, M. sativa, \\
and P. sativum \\
2. Late winter (early spring crops): A. sativa, \\
P. sativum, and H. vulgare \\
3. Spring crops: B. vulgaris, H. annuus, Z. mays, \\
and G. max
\end{tabular}

Following Bohan et al. (2011), we proposed to categorise specific crops and simplify (amalgamate) cropping sequences by assuming that there are similarities between crops and their management. We adapted their classification to assign to each crop type a taxonomic classification, a season of sowing dates and herbicide spectrum

period of crop production or restricted to a very short period, leading to highly contrasted values of return intervals. This is of importance because a long return interval may allow weed emergence, growth and sometimes seed setting.

\subsubsection{Types of disturbances}

Chemical disturbances Chemical disturbances mainly refer to herbicide applications. Here, we assume that other pesticides such as fungicides do not affect weed performance. The remaining weed communities after herbicide treatment will depend on the selectivity of the herbicide, the applied dose and the sensitivity of the plant. Chemical disturbances can be described by the active ingredient of herbicide and the dose which refers to the severity and the intensity of the disturbance, respectively. Herbicides have different spectrums according to the active ingredient. Some selective herbicides have narrow spectrums and hence are limited in the number of weed species that can be controlled (Brown 1990), e.g. some ACCase inhibitors control more specifically grasses while phenoxycarboxylic acid herbicides strictly control broadleaf species. On the opposite, broad spectrum herbicides (e.g. ALS inhibitors like sulfonylurea herbicides) are more effective in controlling a large number of weed species. Finally, nonselective herbicides (e.g. glyphosate) can affect a wide range of weed species (annual and perennial and grass and broadleaf species). The dose is usually recommended for a given crop; however, to reduce their herbicide use, farmers can reduce the dose modulating the efficiency of the herbicides (Andersson 1996). We, thus, propose to classify chemical disturbances according to their severity, i.e. spectrum and their intensity, i.e. dose (Table 2). Given the variability in the efficiency of an herbicide in controlling weed species, the classification remains categorical. The first level is the level 0 which refers to a 'no-herbicide' application such as in organic cropping systems. The two following levels, 1 and 2, include specific weed control of broad-leaf or grass weed species. These two levels vary according to the dose applied: less than or $50 \%$ of the recommended dose for level 1 and between more than 50 and $100 \%$ of the recommended dose for level 2 . Similarly, the levels 3 and 4 include large spectrum weed control with less than or $50 \%$ of the recommended dose for level 3 and between more than 50 and $100 \%$ of the recommended dose for level 4 . Finally, the levels 5 and 6 , which also diverge according to the dose applied, refer to non-selective herbicides that can be systemic, e.g. glyphosate. When several herbicides are used with nested effects, we suggest taking the highest level (recommended dose) which would be the more relevant measure of the treatment severity. For the specific case of the combined use of an herbicide controlling broadleaf species and one controlling grass species, the level of severity would be 3 or 4 according to the dose applied, assuming that their effect would be roughly similar to large spectrum herbicides.

Physical disturbances Physical disturbances related to crop management are due to the use of machines that cause changes in soil environment and biomass destruction at both aboveand below-ground levels. Above-ground physical disturbances are related to crop reaping and stubble grounding. Considering that they act similarly among crops, they are not described in more details thereafter. Conversely, belowground physical disturbances can be highly contrasted, depending on the environmental context. They include three different kinds of operation: (1) tillage that splits the soil up, prepares the soil before crop sowing and burry weeds and crop residuals, (2) mechanical weeding during crop growth especially for crops with wide rows and (3) harvest of root crops that involves specific harvesting machines, i.e. for sugar beet or potato, and consists in digging furrows in the soil. The outcome of below-ground disturbances varies with respect to both the characteristics of the operation, such as depth, inversion angle, width, speed, number of passes and the tool and the characteristics of the soil that is being tilled, such as texture, structure and moisture (Roger-Estrade et al. 2004; Roger-Estrade et al. 2009). However, depth and inversion appear to be of major importance on weed biomass destruction and seed movements into the soil profile (Mohler and Galford 1997; Roger-Estrade et al. 2006). 
(a)

\begin{tabular}{|c|c|c|c|c|c|c|c|c|}
\hline & $\begin{array}{c}\text { Crop } \\
\mathbf{t}\end{array}$ & $\begin{array}{c}\text { Crop } \\
\text { t-1 }\end{array}$ & $\begin{array}{c}\text { Crop } \\
\text { t-2 }\end{array}$ & $\begin{array}{c}\text { Crop } \\
\text { t-3 }\end{array}$ & $\begin{array}{c}\text { Crop } \\
\text { t-4 }\end{array}$ & $\begin{array}{c}\text { Crop } \\
\text { t-5 }\end{array}$ & $\begin{array}{c}\text { Crop } \\
\text { t- } 6\end{array}$ & \\
\hline Crop & $\begin{array}{l}\text { Winter } \\
\text { wheat }\end{array}$ & $\begin{array}{l}\text { Winter } \\
\text { wheat }\end{array}$ & $\begin{array}{l}\text { Winter } \\
\text { wheat }\end{array}$ & $\begin{array}{l}\text { Winter } \\
\text { wheat }\end{array}$ & $\begin{array}{l}\text { Winter } \\
\text { wheat }\end{array}$ & $\begin{array}{l}\text { Winter } \\
\text { wheat }\end{array}$ & $\begin{array}{l}\text { Winter } \\
\text { wheat }\end{array}$ & \\
\hline Sowing period & w & w & w & w & w & w & w & Mean $=1$ \\
\hline & & 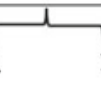 & $\lambda$ & $\tau$ & & $\gamma_{1}$ & & $C V=0$ \\
\hline
\end{tabular}

(b)

\begin{tabular}{|c|c|c|c|c|c|c|c|c|}
\hline & $\begin{array}{c}\text { Crop } \\
t\end{array}$ & $\begin{array}{c}\text { Crop } \\
t-1\end{array}$ & $\begin{array}{c}\text { Crop } \\
t-2\end{array}$ & $\begin{array}{c}\text { Crop } \\
t-3\end{array}$ & $\begin{array}{c}\text { Crop } \\
\mathrm{t}-4\end{array}$ & $\begin{array}{c}\text { Crop } \\
\text { t-5 }\end{array}$ & $\begin{array}{c}\text { Crop } \\
\text { t-6 }\end{array}$ & \\
\hline Crop & $\begin{array}{l}\text { Winter } \\
\text { wheat }\end{array}$ & Maize & Maize & $\begin{array}{l}\text { Oilseed } \\
\text { rape }\end{array}$ & $\begin{array}{l}\text { Winter } \\
\text { wheat }\end{array}$ & $\begin{array}{l}\text { Winter } \\
\text { barley }\end{array}$ & $\begin{array}{c}\text { Oilseed } \\
\text { rape }\end{array}$ & \multirow{3}{*}{$\begin{array}{l}\text { Mean }=2.17 \\
C V=0.54\end{array}$} \\
\hline Sowing period & w & $\mathrm{sp}$ & $s p$ & w & w & $w$ & w & \\
\hline & & & & 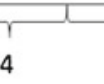 & & 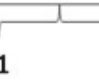 & & \\
\hline
\end{tabular}

(c)

\begin{tabular}{|c|c|c|c|c|c|c|c|c|}
\hline & $\begin{array}{c}\text { Crop } \\
t\end{array}$ & $\begin{array}{l}\text { Inter- } \\
\text { crop t }\end{array}$ & $\begin{array}{c}\text { Crop } \\
\text { t-1 }\end{array}$ & $\begin{array}{c}\text { Crop } \\
\text { t-2 }\end{array}$ & $\begin{array}{c}\text { Crop } \\
\text { t-3 }\end{array}$ & $\begin{array}{c}\text { Crop } \\
\text { t-4 }\end{array}$ & $\begin{array}{c}\text { Crop } \\
\text { t- } 5\end{array}$ & \\
\hline Crop & $\begin{array}{l}\text { Winter } \\
\text { wheat }\end{array}$ & $\begin{array}{l}\text { Cash } \\
\text { crop }\end{array}$ & $\begin{array}{l}\text { Winter } \\
\text { wheat }\end{array}$ & Maize & Lucerne & Lucerne & $\begin{array}{l}\text { Winter } \\
\text { wheat }\end{array}$ & \\
\hline Sowing period & $w$ & su & w & $\mathrm{sp}$ & $\mathrm{p}$ & $\mathrm{p}$ & w & Mean $=3.67$ \\
\hline & 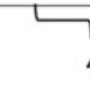 & & $\lambda$ & 3 & $\begin{array}{l}r \\
5\end{array}$ & 1 & $\begin{array}{l}\gamma \\
5\end{array}$ & $C V=0.51$ \\
\hline
\end{tabular}

Fig. 3 Legacy from past disturbance regimes. The variation in the past disturbance regimes is based on the magnitude of the inter-year transition in the crop sequence. This transition is characterised by the change in sowing dates and in herbicide target between two successive crops, to which we assign a value. The mean of the transition refers to magnitude of differences between successive crops in the succession. The coefficient of variation of the differences between transitions is computed: the lower this value, the lower the variation in the crop sequence. When no changes are observed, the value of the variation is 0, i.e. for a monoculture. a Example of a monoculture of winter wheat. The same crop is grown

We propose to describe these disturbances into five levels of magnitude depending on soil depth and inversion (see Fig. 4 for an illustration). Level 0 corresponds to a soil disturbance limited to the seed row in conservation tillage systems (no tillage and direct seeding under cover), where most of crop and weed residuals remain on the soil. Levels 1 and 2 correspond to reduced tillage systems without soil inversion, that involve the use of chisel plow, field cultivator or other implements. Minimum tillage (level 1) implies a disturbance down to approximately $10 \mathrm{~cm}$ while a reduced tillage (level 2 ) includes deeper cultivation down to $15 \mathrm{~cm}$. The threshold between the two levels is based on weed seed response: most of the seeds are concentrated within the top $5-\mathrm{cm}$ soil layers (Reuss et al. 2001), whereas only few species depending on seed mass can emerge below $10 \mathrm{~cm}$ (Gardarin et al. 2010a). Levels 3 and 4 correspond to regular and deep ploughing with soil during six successive years with approximately the same sowing year each cropping season. Each pattern of two successive crops corresponds to a level 1. No variation in the crop sequence are observed, hence the crop sequence can denoted by a value of 0 . $\mathbf{b}$ Example of a diverse crop sequence. The crop sequence includes crops sown in winter and in spring with 2 years of maize crop in a monoculture. c Example of a crop sequence with a cash crop and two successive years of Lucerne. The occurrence of a cash crop is treated as a crop. The mean is higher than the preceding one suggesting higher differences if crop types (sowing dates and herbicide targets) in the crop sequence

inversion that are generally related to the use of mouldboard plough. The working depth is between 10 and $25 \mathrm{~cm}$ for level 3 and below $25 \mathrm{~cm}$ for level 4 , with the consequence of depletion of bud and rhizome reserves and prevention of perennial species regrowth (Brandsæter et al. 2010). Level 4 also corresponds to root crop harvest that does not include soil inversion but may cause compaction (Koch et al. 2008).

\section{Weed response traits to management practices}

Trait-based approaches are widely used in ecological studies ranging from the individual to the ecosystem. Considerable effort has been devoted to the identification of traits sensu (Violle et al. 2007) that are relevant proxies of plant 


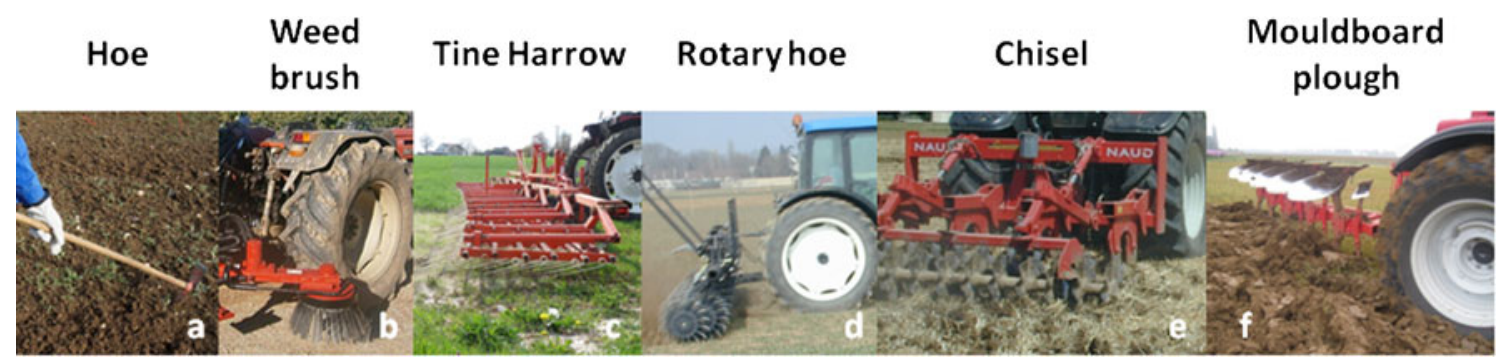

Fig. 4 Physical disturbances induced by various agricultural tools which are ordered according to their levels of magnitude of disturbances (a, $\mathbf{c}, \mathbf{d}$ INRA; b Naturagriff; e, f Farcy, personal communication)

functioning (Garnier et al. 2007; Cornelissen et al. 2003; McIntyre 2008). Similarly, many response traits of weeds to major crop systems have been identified so far (Storkey 2006; Fried et al. 2012; Navas 2012). However, since environmental differences among crop systems represent complex gradients, these traits may not be relevant to characterise and interpret the whole range of weed responses to the direct gradients we identified here (Garnier and Navas 2011). Therefore, we propose a three-step procedure for detecting traits responding to each one of the direct gradients. A first step involves using a priori classification - or functional types - of weeds based on differences in life form, morphology or resource acquisition types, as traditionally performed in early weed research (Hakansson 2003). A second step is the selection of traits representative of suites of co-varying traits that show meaningful relationships with plant functions, as largely documented in the ecological literature (Weiher et al. 1999); for example, the leaf-height-seed (LHS) scheme summarises the major dimensions of variation in plant responses to environment (Westoby 1998), distinguishing traits related to resource use (L), competition ability $(\mathrm{H})$ and regeneration $(\mathrm{S})$. A second advantage of this framework is that it can be used for comparing species among sites and studies in order to establish predictions of community assembly and functioning under a large range of environmental conditions (Garnier and Navas 2013). Lastly, its advantage over classifications identifying two, e.g. the $\mathrm{r} / \mathrm{K}$ strategies (MacArthur and Levins 1967) or three strategies, e.g. the CSRs strategies (Grime 1977) is that weeds are not included into a single category (namely the $\mathrm{r}$ and $\mathrm{R}$ strategies for the two cited classifications, respectively) because these species span a large range in LHS variations. However, some dimensions of weed responses to management cannot be described with this scheme; hence a third step is the identification of a set of more specific traits. In what follows, we illustrate this procedure with results from published literature.

\subsection{Functional types}

Classifications based on life-form are among the most popular for weed researchers because they can be very useful to discriminate weeds according to their responses to below-grown disturbances (Hakansson 1995); for example, soil tillage prevents the establishment of phanerophytes, chamephytes and most of the hemicryptophytes, while its effect on therophytes and perennial species (geophytes with bulbs and tubercules or rhizomes) is more difficult to predict. According to the conditions in which tillage is carried out, perennial weeds with rhizomes or bulbs can either be favoured (division and dispersal of vegetative propagules) or disadvantaged (drying out of the propagules) (Lemieux et al. 1993). In no-tillage or reducedtillage systems, different studies showed that perennial and biennial species are favoured by the discrepancy of soil tillage (Navas 1991; Zanin et al. 1997), leading to more diverse weed communities in such cropping system (Swanton et al. 2006; Légère et al. 2011). Conversely, the densities of annual weeds were found higher than those of perennial weeds in conventional than in reduced tillage (Frick and Thomas 1992; Staniforth and Wiese 1985). Finally, clonal growth is frequently associated with early successional or recently disturbed habitats, where it may serve as a means for quickly exploring and claiming space during an inter-crop period without mechanical intervention. Moreover, the movement of foliar-applied herbicide into the plant can vary among species according to life form, with a transport through phloem towards roots or organ storages for perennial species (Gauvrit 1996; White and Jentsch 2001). Therefore, a classification based on life form may be relevant to identify the response of weeds to physical or chemical disturbances and to the end of disturbances.

\subsection{LHS framework}

The first plant function dimension taken into account into the LHS framework is the resource use dimension. This dimension is related to the fundamental trade-off occurring between the acquisition rate and conservation of resources by plants and is described by a leaf trait syndrome including the specific leaf area (SLA; leaf area-biomass ratio) (Wright et al. 2004). SLA appears to be the most relevant trait to describe the resource use of plants because of high responsiveness to nutrient and light availabilities and easiness of measurement (Garnier and Navas 2011). Very few data on SLA of weeds are available so far, probably because resource use strategies of weeds were thought to be poorly variable in productive crop 
systems. Assimilation rates at light saturation in the field have been documented to be largely determined by SLA for weeds (Storkey 2005), suggesting that this trait might be of interest to distinguish different strategies of resource acquisition by weeds (Table 4).

The second axis of plant functioning of the LHS scheme is competition ability. That dimension is captured by plant height, a trait also associated with whole plant fecundity, seed dispersal and generation time after disturbance (Westoby et al. 2002). The link between plant height and competition ability is explained by the positive relationship between that trait and light and water acquisition over a growing season (Violle et al. $2009 \mathrm{~b}$ and references therein). The differential of dynamics of height growth among interacting plants is also of major influence on competitive outcome (Navas and Violle 2009) as

Table 4 Summary of weed response traits to crop effect traits assessing the resource gradient assessed by crop effect traits and to the seven parameters defining the disturbance gradient, which are discussed in the text

\begin{tabular}{|c|c|c|}
\hline & Gradient parameter & Weed response traits \\
\hline \multirow{8}{*}{$\begin{array}{l}\text { Resource } \\
\text { gradients }\end{array}$} & \multirow{2}{*}{$\begin{array}{l}\text { Crop height at canopy } \\
\text { closure }\end{array}$} & SLA \\
\hline & & Height growth rate \\
\hline & \multirow[t]{4}{*}{ Crop maximal height } & SLA \\
\hline & & Height growth rate \\
\hline & & Maximal plant height \\
\hline & & Seed mass \\
\hline & Date of sowing & Life form germination date \\
\hline & Flowering date & Maximal plant height \\
\hline \multirow{21}{*}{$\begin{array}{c}\text { Disturbance } \\
\text { gradient }\end{array}$} & \multirow{4}{*}{$\begin{array}{l}\text { Legacy from past } \\
\text { disturbance }\end{array}$} & Life form \\
\hline & & Seed mass \\
\hline & & Seed coat thickness \\
\hline & & Germination date \\
\hline & Onset of disturbance & Germination date \\
\hline & \multirow[t]{3}{*}{ End of disturbance } & Life form \\
\hline & & Flowering date \\
\hline & & Seed setting \\
\hline & \multirow[t]{3}{*}{ Frequency } & Maximal plant height \\
\hline & & Seed mass \\
\hline & & Flowering date and range \\
\hline & \multirow[t]{3}{*}{ Return interval } & SLA \\
\hline & & Height growth rate \\
\hline & & Flowering date and range \\
\hline & \multirow[t]{3}{*}{ Chemical disturbance } & Life form \\
\hline & & Leaf surface traits \\
\hline & & Plant phenology \\
\hline & \multirow[t]{4}{*}{ Physical disturbance } & Life form \\
\hline & & Seed mass \\
\hline & & Seed coat thickness \\
\hline & & Flowering date and range \\
\hline
\end{tabular}

$S L A$ specific leaf area demonstrated for annual weed stands (Turnbull et al. 2004) and maize-weed interactions (McDonald et al. 2010). Reproductive height at which flowers and seeds are produced is also a good indicator of plant reproduction success and dispersal (Bazzaz et al. 2000). Moreover, reproductive output of a plant can be linearly related to its size (Weiner 1988) and see empirical evidences in (Warwick and Thompson 1987) for Panicum miliaceum; (Sans and Massalles 1994) for Diplotaxis erucoides). Furthermore, plant height is constrained by the frequency of disturbances, with smaller plants being found in more disturbed places (Díaz et al. 1992; Sonnier et al. 2012; Fried et al. 2012). Therefore, the analysis of plant height in different cropping systems could give insights into weed response to competition and their capacity to reproduce and disperse according to disturbance regime and timing (Table 4).

The third dimension of plant functioning, regeneration, is captured by seed mass. Seed mass affects almost all aspects of plant ecology, including dispersal, seedling establishment and persistence (Salisbury 1942; Harper et al. 1970; Westoby 1998; Weiher et al. 1999; Fenner and Thompson 2005). Larger seeds confer an advantage of higher seedling survival under competitive environment (Turnbull et al. 1999; Marshall 1986), at least on a relatively short term (Moles and Westoby 2004), and a greater success of emerging from burial (Gardarin et al. 2009, 2010a) but are less dispersible due to their greater mass (Fenner 1985). Therefore, seed mass determines both competitive and colonising ability via a tradeoff between the production of numerous small seeds and fewer larger seeds from a given quantity of resource allocated to reproduction (Rees and Westoby 1997; Turnbull et al. 1999; Moles and Westoby 2004). Seed mass may also be related to persistence in the soil (Bekker et al. 1998; Fenner and Thompson 2005)( and to disturbances (McIntyre et al. 1999). In arable land, seed mass negatively correlates with the intensity of disturbances: small-seeded species have a better chance to escape the effects of frequent disturbance than large-seeded species that are favoured under dense plant cover (Albrecht and Auerswald 2009). Therefore, seed mass is a relevant candidate to study the response of weeds to change in the crop sequence, below-ground disturbances and the frequency of disturbances (Table 4).

\subsection{Specific response traits}

As stressed above, a third group of traits of weeds must be identified to specifically address weed response to some major events of the crop cycle. Evidence for most of the traits discussed below remains to be documented for a large number of species and situations; hence, analysis should be conducted on this topic in the future.

First, seed coat thickness has recently been recognised to be negatively correlated with seed mortality in the seed bank (Gardarin et al. 2010b). A thick seed coat can provide the 
seed embryo with efficient protection against external aggressions caused by microorganisms and other abiotic factors, such as temperature and moisture variations. Moreover, seed coat properties can be related to seed dormancy (Baskin and Baskin 1998), which could result in a correlation between mortality and dormancy. A relationship between these two processes is also expected as there is no advantage in being dormant and avoiding early germination if the seeds do not survive to germinate in later seasons. These promising results make seed coat thickness an easy-to-measure trait that can be used to predict soil seed persistence in the seed bank and thus to predict weed response to crop sequence and below-ground disturbances.

Second, leaf surface traits can affect the wetting and penetration of foliar applied herbicides (Hull et al. 1982). Leaf surface traits include the cuticle (epicuticular wax, pectin and cutin), the hairiness (number of trichomes) and the surface cells (number of stomata and cell size). These traits vary according to leaf age and development (Hess 1985; Wanamarta and Penner 1989). Among surface leaf traits, the epicuticular wax is considered to be an effective barrier to herbicide absorption (DiTomaso 1999; Pierce et al. 2001): the spray droplet coverage decreases when the amount of epicuticular wax increases, leading to a reduction in herbicide quantity in contact with the leaf surface (Hess and Falk 1990). According to the number of trichomes, leaf hairs can retain herbicide droplets or intercept droplets, holding them away from the leaf surface or increasing the foliar uptake (Grangeot et al. 2006). The easier control of seedlings is mainly explained by occurrence of fewer and shorter hairs. Nevertheless this tolerance to herbicide is generally compensated for by addition of surfactants or wetting agents which reduce the surface tension of water droplets and increase the surface contact with plant. Therefore, the screening values of these traits for detecting weed response to herbicide remains to be established.

Finally, the temporal aspect of plant establishment and development which is seldom taken into account for other species, determines weed response to agricultural disturbances (Ghersa and Holt 1995). Opportunities for germination and seed production are highly dependent on the phenological weed traits and the timing of disturbances defined by the dates of crop sown and harvest. Gunton et al. (2011) demonstrated that the germination and flowering dates are important descriptors of weed community composition. These results, confirmed by Fried et al. (2012), have shown that weeds with late germination date are more abundant in latesown wheat fields than species with early germination date. Dynamics of height growth that depend on both resource and disturbance regime at a site, modulate competitive outcome between weeds and crop (McDonald et al. 2010). Lastly, onset of flowering depends on the intensity and frequency of soil disturbances, and determines seed production before herbicide application (Storkey 2006; Fried et al. 2012). As a consequence, we suggest that germination onset and range, flowering onset and range and phenology of growth are relevant traits for studying weed responses to the timing and frequency of disturbances. Clearly, more research is needed to define relationships among all phenological traits before selecting the most representative.

\section{Conclusions and perspectives}

In this paper, we proposed an agro-ecological framework for comparing the response of weed species and the functional structure of communities they form among environmental conditions created by cropping systems. We believe that our framework, which encapsulates concepts from both agronomy and ecology, will improve the understanding of weed community assembly and allow predicting weed flora under environmental conditions generated by new and more sustainable cropping systems.

Beyond being original, the description of cropping systems into environmental gradients would allow to analyse the distribution of weed response traits along these gradients and to test for processes that underlie weed species assembly (Cornwell and Ackerly 2009; Garnier and Navas 2011). Such an investigation represents an alternative to current models of agricultural effects on weed communities, e.g. Colbach et al.'s (2006) which rely on detailed cropping system $\times$ environment interactions to predict weed dynamics. To that aim, the test of the validity of the method we proposed to assess environmental gradients remains to be done. This test requires gathering datasets on disturbance components due to agricultural practices. Contrary to other disturbed environments, disturbances in arable fields are driven by human decision. As a consequence, information is needed not only on the agricultural techniques (herbicide and fertiliser use, ploughing, tillage and mechanical weed control regime) but also on the farming practices, i.e. the decision rules of famers which generated the combination of techniques and their timing of applications. These should be collected by means of a questionnaire which must be carefully built to get all the data required to describe the regimes and types of disturbances (see Table 2). Further investigations are also needed to characterise the effect traits of crops in a large range of cropping systems occurring in highly distinct regions.

Beside precise data on agricultural practices, local conditions (i.e. soil and climatic conditions) and crop traits, it is necessary to select the relevant response traits of weeds and to define how to measure their attributes. We suspect that the use of current trait databases (e.g. LEDA (Kleyer et al. 2008) or TRY (Kattge et al. 2012) is not appropriated for weeds because of sampling specificity. Indeed, the standardised 
procedures for measuring traits on plants, e.g. Cornelissen et al.'s (2003), are not appropriate for most of weeds because of a rather low density in managed fields and location in shady environment induced by crop coverage. Furthermore, individual plants within a local population might exhibit different ecological strategies because they establish and grow at different periods over the crop growth period. We, thus, suggest that guidelines for sampling weed traits in relation to crop development should be established, addressing specifically the estimation of the intraspecific variability of traits that might be of importance to depict the weed community response to cropping system (Violle et al. 2012). This would require rethinking the sampling period of arable flora, usually done at the seedling stage, so that it matches with the filters studied.

In this paper, we focused on weed response traits to gradients. The identification of their effect traits, and how they influence agroecosystem processes, is however a crucial issue for future research. A sustainable weed management should be designed to decrease weed negative impact on crop production while preserving their positive impact on trophic network and local environmental conditions (Storkey and Westbury 2007). To reach that aim, a first step is to identify traits related to each process of interest in the agroecosystem. Some of them have already been determined, for example, weed traits related to competition with the crop are similar to those identified here for characterising the impact of crops on resources, namely plant stature depicted by plant height, basal area or root depth, plant growth rate and phenology. However, traits that could relate to positive effects of weeds on agroecosystem have been seldom documented so far (Navas 2012), although there are some information for other kind of plants (de Bello et al. 2010): occurrence of herbivores is generally related to tissue chemistry, leaf morphology and kind of seed; pollinator provision is explained by floral traits such as accessibility, attractiveness and nectar production; soil protection depends on canopy size or growth form root architecture; seed predation by granivorous rodents (Janzen 1971) or birds is related to seed coat (Lundgren and Rosentrater 2007) or seed energy content (Collas et al., unpublished data). Thus, our conceptual framework could be adapted to investigate weedinvertebrate interaction as long as the response/effect traits are known.

To conclude, we propose an application of contemporary ecology theory to man-managed ecosystems, the use of which would give important insights for supporting decision making in weed management. Ecological theory is already being used for making resource management decisions improvement in conservation; however, its inappropriate application has led to detrimental management outcomes (but see Driscoll and Lindenmayer 2012 for further details). Adaptation of ecological theory to agroecosystems is therefore needed. Similar attempts should be done to properly characterise environmental gradients and factors affecting weeds at landscape scale.

\section{References}

Albrecht H, Auerswald K (2009) Seed traits in arable weed seed banks and their relationship to land-use changes. Basic Appl Ecol 10(6):516-524

Altieri MA (1989) Agroecology: a new research and development paradigm for world agriculture. Agric Ecosyst Environ 27:37-46

Altieri MA, Rosset P (1995) Agroecology and the conversion of largescale conventional systems to sustainable management. Int J Environ Stud 50:165-185

Andersson L (1996) Characteristics of seeds and seedlings from weeds treated with sublethal herbicide doses. Weed Res 36:55-64

Austin MP (1980) Searching for a model for use in vegetation analysis. Vegetatio 42:11-21

Austin MP, Smith TM (1989) A new model for the continuum concept. Vegetatio 83:35-47

Ball D (1992) Weed seedbank response to tillage, herbicides, and crop rotation sequence. Weed Sci 40:654-659

Baskin CC, Baskin JM (1998) Seeds: ecology, biogeography, and evolution of dormancy and germination. Academic Press, San Diego

Bazzaz FA, Ackerly DD, Reekie EG (2000) Reproductive allocation in plants. In: Fenner M (ed) Seeds: the ecology of regeneration in plant communities. CABI Publishing, Wallingford, pp 1-30

Bekker RM, Bakker JP, Grandin U, Kalamees R, Milberg P, Poschlod P, Thompson K, Willems JH (1998) Seed size, shape and vertical distribution in the soil: indicators of seed longevity. Funct Ecol 12:834-842

Benjamin LR, Sutherland RA, Senior D (1985) The influence of sowing date and row spacing on the plant-density and yield of red beet. J Agric Sci 104:615-624, JUN

Bohan DA, Powers SJ, Champion G, Haughton AJ, Hawes C, Squire G, Cussans J, Mertens SK (2011) Modelling rotations: can crop sequences explain arable weed seedbank abundance? Weed Res 51(4):422-432. doi:10.1111/j.1365-3180.2011.00860.x

Booth BD, Swanton CJ (2002) Assembly theory applied to weed communities. Weed Sci 50:2-13

Bornette GE, Tabacchi E, Hupp C, Puijalon S, Rostan JC (2008) A model of plant strategies in fluvial hydrosystems. Freshw Biol 53(8):1692-1705

Bossuyt B, Honnay O (2008) Can the seed bank be used for ecological restoration? An overview of seed bank characteristics in European communities. J Veg Sci 19(6):875-884. doi:10.3170/2008-8-18462

Boulant N, Kunstler G, Rambal S, Lepart J (2008) Seed supply, drought, and grazing determine spatio-temporal patterns of recruitment for native and introduced invasive pines in grasslands. Divers Distrib 14(5):862-874

Brandsæter L, Fogelfors H, Fykse H, Graglia E, Jensen RK, Melander B, Salonen J, Vanhala P (2010) Seasonal restrictions of bud growth on roots of Cirsium arvense and Sonchus arvense and rhizomes of Elymus repens. Weed Sci 50:102-109

Brown HM (1990) Mode of action, crop selectivity, and soil relations of the sulfonylurea herbicides. Pestic Sci 29(3):263-281. doi:10. 1002/ps.2780290304

Cardinale BJ, Matulich KL, Hooper DU, Byrnes JE, Duffy E, Gamfeldt L, Balvanera P, O'Connor MI, Gonzalez A (2011) The functional role of producer diversity in ecosystems. Am J Bot 98(3):572-592. doi:10.3732/ajb.1000364 
Chikowo R, Faloya V, Petit S, Munier-Jolain NM (2009) Integrated weed management systems allow reduced reliance on herbicides and long-term weed control. Agric Ecosyst Environ 132(34):237-242. doi:10.1016/j.agee.2009.04.009

Cirujeda A, Aibar J, Zaragoza C (2011) Remarkable changes of weed species in Spanish cereal fields from 1976 to 2007. Agron Sustain Dev 31:675-688

Clements DR, Benoit DL, Swanton CJ (1996) Tillage effects on weed seed return and seedbank composition. Weed Sci 44:314-322

Colbach N, Busset H, Yamada O, Dürr C, Caneill J (2006) ALOMYSYS: modelling black-grass (Alopecurus myosuroides Huds.) germination and emergence, in interaction with seed characteristics, tillage and soil climate. II. Evaluation. Eur J Agron 24:113-128

Cornelissen JHC, Lavorel S, Garnier E, Diaz S, Buchmann N, Gurvich DE, Reich PB, ter Steege H, Morgan HD, van der Heijden MGA, Pausas JG, Poorter H (2003) A handbook of protocols for standardised and easy measurement of plant functional traits worldwide. Austr J Bot 51:335-380

Cornwell WK, Ackerly DD (2009) Community assembly and shifts in the distribution of trait values across an environmental gradient in coastal California. Ecol Monogr 79:109-126

Cousens R, Mortimer M (1995) Dynamics of weed populations. Canada, Toronto

Cruz P, Jouany C, Theau J-P, Petibon P, Lecloux E, Duru M (2006) L'utilisation de l'indice de nutrition azotée en prairies naturelles avec présence de légumineuses. Fourrages 187:369-376

de Bello F, Lavorel S, Diaz S, Harrington R, Cornelissen JHC, Bardgett RD, Berg MP, Cipriotti P, Feld CK, Hering D, da Silva PM, Potts SG, Sandin L, Sousa JP, Storkey J, Wardle DA, Harrison PA (2010) Towards an assessment of multiple ecosystem processes and services via functional traits. Biodivers Conserv 19(10):28732893. doi:10.1007/s10531-010-9850-9

de Gournay X (1963) La lutte contre le vulpin des champs (Alopecurus myosuroides Huds.) dans les cultures de blé d'hiver. Ann Physiol Vég 5(3):229-247

Dessaint F, Barralis G, Beuret E, Caixinhas ML, Post BJ, Zanin G (1990) Etude coopérative EWRS: la détermination du potentiel semencier: I. Recherche d'une relation entre la moyenne et la variance d'échantillonnage. Weed Res 30:421-429

Díaz S, Acosta A, Cabido M (1992) Morphological analysis of herbaceous communities under different grazing regimes. J Veg Sci 3:689-696

DiTomaso JM (1999) Barriers to foliar penetration and uptake of herbicides. In: Proceedings of the California Weed Science Society, 1999, pp 150-155

Driscoll DA, Lindenmayer DB (2012) Framework to improve the application of theory in ecology and conservation. Ecol Monogr 82(1):129-147. doi:10.1890/11-0916.1

Fenner M (1985) Seed ecology. Chapman \& Hall, London

Fenner M, Thompson K (2005) The ecology of seeds. Cambridge University Press, Cambridge

Frick B, Thomas AG (1992) Weed surveys in different tillage systems in south western Ontario field crops. Can J Plant Sci 72:13321347

Fried G, Norton LR, Reboud X (2008) Environmental and management factors determining weed species composition and diversity in France. Agric Ecosyst Environ 128(1-2):68-76

Fried G, Chauvel B, Reboud X (2009) A functional analysis of largescale temporal shifts from 1970 to 2000 in weed assemblages of sunflower crops in France. J Veg Sci 20(1):49-58. doi:10.1111/j. 1654-1103.2009.05284.x

Fried G, Kazakou E, Gaba S (2012) Trajectories of weed communities explained by traits associated with species' response to management practices. Agric Ecosyst Environ 158:147-155. doi:10.1016/ j.agee.2012.06.005
Gardarin A, Durr C, Colbach N (2009) Which model species for weed seedbank and emergence studies? A review. Weed Res 49(2):117130. doi:10.1111/j.1365-3180.2008.00683.x

Gardarin A, Durr C, Colbach N (2010a) Effects of seed depth and soil aggregates on the emergence of weeds with contrasting seed traits. Weed Res 50(2):91-101. doi:10.1111/j.1365-3180.2009.00757.x

Gardarin A, Durr C, Mannino MR, Busset H, Colbach N (2010b) Seed mortality in the soil is related to seed coat thickness. Seed Sci Res 20(4):243-256. doi:10.1017/s0960258510000255

Garnier E, Navas M-L (2011) A trait-based approach to comparative functional plant ecology: concepts, methods and applications for agroecology. A review. Agron Sustain Dev 1-35. doi:10.1007/ s13593-011-0036-y

Garnier E, Navas M-L (2013) Diversité Fonctionnelle des Végétaux. De Boeck

Garnier E, Lavorel S, Ansquer P, Castro H, Cruz P, Dolezal J, Eriksson O, Fortunel C, Freitas H, Golodets C, Grigulis K, Jouany C, Kazakou E, Kigel J, Kleyer M, Lehsten V, Leps J, Meier T, Pakeman R, Papadimitriou M, Papanastasis VP, Quested H, Quétier F, Robson M, Roumet C, Rusch G, Skarpe C, Sternberg M, Theau J-P, Thébault A, Vile D, Zarovali MP (2007) Assessing the effects of land-use change on plant traits, communities and ecosystem functioning in grasslands: a standardized methodology and lessons from an application to 11 European Sites. Ann Bot 99(5):967-985. doi:10.1093/aob/mcl215

Gauvrit C (1996) Efficacité et sélectivité des herbicides. Editions INRA, Paris

Ghersa CM, Holt JS (1995) Using phenology prediction in weed management: a review. Weed Res 35:461-470

Gliessman SR (2006) Agroecology: the ecology of sustainable food systems, 2nd edn. CRC Press, Boca Raton

Grangeot M, Chauvel B, Gauvrit C (2006) Spray retention, foliar uptake and translocation of glufosinate and glyphosate in Ambrosia artemisiifolia. Weed Res 46(2):152-162

Grime JP (1977) Evidence for the existence of three primary strategies in plants and its relevance to ecological and evolutionary theory. Am Nat 111:1169

Grime JP (1979) Plant strategies and vegetation processes. Wiley, New York

Grime JP (1998) Benefits of plant diversity to ecosystems: immediate, filter and founder effects. J Ecol 86(6):902-910. doi:10.1046/j. 1365-2745.1998.00306.x

Gross N, Suding KN, Lavorel S (2007) Leaf dry matter content and lateral spread predict response to land use change for six subalpine grassland species. J Veg Sci 18:289-300

Gross N, Robson TM, Lavorel S, Albert C, Le Bagousse-Pinguet Y, Guillemin R (2008) Plant response traits mediate the effects of subalpine grasslands on soil moisture. New Phytol 180(3):652-662

Gunton RM, Petit S, Gaba S (2011) Functional traits relating arable weed communities to crop characteristics. J Veg Sci 22:541-550. doi:10.1111/j.1654-1103.2011.01273.x

Hakansson S (1995) Weeds in agricultural crops. 3. Life forms, C3 and $\mathrm{C} 4$ photosynthesis and plant families in a global perspective. Swed J Agric Res 25:163-171

Hakansson S (2003) Weeds and weed management on arable lands: an ecological approach. CABI Publishing, London

Harper JL, Lovell PH, Moore KG (1970) The shapes and sizes of seeds. Annu Rev Ecol Syst 1:327-356

Hess DF (1985) Herbicide absorption and translocation and their relationship to plant tolerances and susceptibility. In: Weed physiology. CRC Press, Boca Raton. pp 191-214

Hess FD, Falk RH (1990) Herbicide deposition on leaf surfaces. Weed Sci 38(3):280-288

Hull HM, Davis DG, Stolzenberg GE (1982) Actions of adjuvant on plant surface. In: Hodgson RH (ed) Adjuvants for herbicides. WSSS, Champaign 
Huston MA (1979) A general hypothesis of species diversity. Am Nat $113: 81-101$

IFEN (2007) Les Pesticides dans les Eaux-Données 2005. Institut Français de l'Environnement, Orléans

Janzen DH (1971) Seed predation by animals. Annu Rev Ecol Syst 2:465-492

Kattge J, Diaz S, Lavorel S, Prentice C, Leadley P, Bonisch G, Garnier E, Westoby M, Reich PB, Wright IJ, Cornelissen JHC, Violle C, Harrison SP, van Bodegom PM, Reichstein M, Enquist BJ, Soudzilovskaia NA, Ackerly DD, Anand M, Atkin O, Bahn M, Baker TR, Baldocchi D, Bekker R, Blanco CC, Blonder B, Bond WJ, Bradstock R, Bunker DE, Casanoves F, Cavender-Bares J, Chambers JQ, Chapin FS, Chave J, Coomes D, Cornwell WK, Craine JM, Dobrin BH, Duarte L, Durka W, Elser J, Esser G, Estiarte M, Fagan WF, Fang J, Fernandez-Mendez F, Fidelis A, Finegan B, Flores O, Ford H, Frank D, Freschet GT, Fyllas NM, Gallagher RV, Green WA, Gutierrez AG, Hickler T, Higgins SI, Hodgson JG, Jalili A, Jansen S, Joly CA, Kerkhoff AJ, Kirkup D, Kitajima K, Kleyer M, Klotz S, Knops JMH, Kramer K, Kuhn I, Kurokawa H, Laughlin D, Lee TD, Leishman M, Lens F, Lenz T, Lewis SL, Lloyd J, Llusia J, Louault F, M.A. S, Mahecha MD, Manning P, Massad T, Medlyn BE, Messier J, Moles AT, Muller SC, Nadrowski K, Naeem S, Niinemets U, Nollert S, Nuske A, Ogaya R, Oleksyn J, Onipchenko VG, Onoda Y, Ordonez J, Overbeck G, Ozinga WA, Patino S, Paula S, Pausas JG, Penuelas J, Phillips OL, Pillar V, Poorter H, Poorter L, Poschlod P, Prinzing A, Proulx R, Rammig A, Reinsch S, Reu B, Sack L, SalgadoNegre B, Sardans J, Shiodera S, Shipley B, Siefert A, Sosinski E, Soussana JF, Swaine E, Swenson N, Thompson K, Thornton P, Waldram M, Weiher E, White M, White S, Wright SJ, Yguel B, Zaehle S, Zanne AE, Wirth C (2012) TRY - a global database of plant traits. Glob Chang Biol 17(9):2905-2935. doi:10.1111/j. 1365-2486.2011.02451.x

Kleyer M, Bekker RM, Knevel IC, Bakker JP, Thompson K, Sonnenschein M, Poschlod P, van Groenendael JM, Klimes L, Klimesová J, Klotz S, Rusch GM, Hermy M, Adriaens D, Boedeltje G, Bossuyt B, Endels P, Götzenberger L, Hodgson JG, Jackel A-K, Dannemann A, Kühn I, Kunzmann D, Ozinga WA, Römermann C, Stadler M, Schlegelmilch J, Steendam HJ, Tackenberg O, Wilmann B, Cornelissen JHC, Eriksson O, Garnier E, Fitter A, Peco B (2008) The LEDA Traitbase: a database of lifehistory traits of the Northwest European flora. J Ecol 96:1266-1274

Koch H-J, Heuer H, Tomanova O, Maerlaender B (2008) Cumulative effect of annually repeated passes of heavy agricultural machinery on soil structural properties and sugar beet yield under two tillage systems. Soil Tillage Res 1001(1-2):69-77. doi:10.1016/j.still.2008.07.008

Kropáč Z, Hadač E, Hejný S (1971) Some remarks on the synecological and syntaxonomic problems of weed plant communities. Preslia 43:139-153

Kühner A, Kleyer M (2008) A parsimonious combination of functional traits predicting plant response to disturbance and soil fertility. $\mathrm{J}$ Veg Sci 19:681-692

Larcher W (2003) Physiological plant ecology: ecophysiology and stress physiology of functional groups. Springer, Berlin

Lavorel S, Garnier E (2002) Predicting changes in community composition and ecosystem functioning from plant traits: revisiting the Holy Grail. Funct Ecol 16:545-556

Lavorel S, Touzard B, Lebreton J-D, Clément B (1998) Identifying functional groups for response to disturbance in an abandoned pasture. Acta Oecol-Int J Ecol 19:227-240

Légère A, Stevenson FC, Benoît D-L (2011) The selective memory of weed seedbanks after 18 years of conservation tillage. Weed Sci 59(1):98-106. doi:10.1614/WS-D-10-00092.1

Lemieux C, Cloutier DC, Leroux GD (1993) Distribution and survival of quackgrass (Elytrigia repens) rhizome buds. Weed Sci 41:600 606
Lewis J (1973) Longevity of crop and weed seeds: survival after 20years in the soil. Weed Res 13:179-191

Lososvà Z, Chutry M, Kühn I, Hàjek $\mathrm{O}$, Horakova V, Pysek P, Tichy L (2006) Patterns of plant traits in annual vegetation of man-made habitats in central Europe. Perspect Plant Ecol, Evol Syst 8:69-81

Lundgren JG, Rosentrater KA (2007) The strength of seeds and their destruction by granivorous insects. Arthropod-Plant Interactions 1(2):93-99

MacArthur R, Levins R (1967) The limiting similarity, convergence, and divergence of coexisting species. Am Nat 101:377-385

Maillet J (1981) Evolution de la flore adventice dans le Montpelliérais sous la pression des techniques culturales. USTL, Montpellier, France

Manalil S, Busi R, Renton M, Powles SB (2011) Rapid evolution of herbicide resistance by low herbicide dosages. Weed Sci 59:210 217

Marshall DL (1986) Effect of seed size on seedling success in three species of Sesbania (Fabaceae). Am J Bot 73:457-464

Marshall EJP, Brown VK, Boatman ND, Lutman PJW, Squire GR, Ward LK (2003) The role of weeds in supporting biological diversity within crop fields. Weed Res 43:77-89

McDonald AJ, Riha SJ, Ditommaso A (2010) Early season height differences as robust predictors of weed growth potential in maize: new avenues for adaptive management? Weed Res 50(2):110-119. doi:10.1111/j.1365-3180.2009.00759.x

McGill BJ, Enquist BJ, Weiher E, Westoby M (2006) Rebuiling community ecology from functional traits. Trends Ecol Evol 21(4):178-185

McIntyre S (2008) The role of plant leaf attributes in linking land use to ecosystem function in temperate grassy vegetation. Agric Ecosyst Environ 128:251-258

McIntyre S, Lavorel S, Landsberg J, Forbes T (1999) Disturbance response in vegetationâ€"towards a global perspective on functional traits. J Veg Sci 10(5):621-630

Meiss H, Le Lagadec L, Munier-Jolain N, Waldhardt R, Petit S (2010) Weed seed predation increases with vegetation cover in perennial forage crops. Agric Ecosyst Environ 138(1-2):10-16. doi:10. 1016/j.agee.2010.03.009

Milberg P, Hallgren E, Palmer MW (2001) Timing of disturbance and vegetation development: how sowing date affects the weed flora in spring-sown crops. J Veg Sci 12(1):93-98. doi:10.2307/3236677

Mohler CL, Galford AE (1997) Weed seedling emergence and seed survival: separating the effects of seed position and soil modification by tillage. Weed Res 37(3):147-155. doi:10.1046/j.13653180.1997.d01-21.x

Moles AT, Westoby M (2004) Seedling survival and seed size: a synthesis of the literature. J Ecol (Oxford) 92:372-383

Moss SR, Storkey J, Cussans JW, Perryman S, Hewitt MV (2004) The Broadbalk long-term experiment at Rothamsted: what has it told us about weeds? Weed Sci 52:864-873

Navas ML (1991) Using plant population biology in weed research - a strategy to improve weed management. Weed Res 31:171-179

Navas ML (2012) Trait-based approaches to unravelling the assembly of weed communities and their impact on agro-ecosystem functioning. Weed Res 52(6):479-488. doi:10.1111/j.1365-3180.2012. 00941.x

Navas ML, Moreau-Richard J (2005) Can traits predict the competitive response of herbaceous Mediterranean species ? Acta Oecol-Int J Ecol 27:107-114

Navas ML, Violle C (2009) Plant traits related to competition: how do they shape the functional diversity of communities? Community Ecol 10(1):131-137

Nicholls C, Altieri M (2013) Plant biodiversity enhances bees and other insect pollinators in agroecosystems. A Rev Agron Sustain Dev 33(2):257-274. doi:10.1007/s13593-012-0092-y

Oerke E-C (2006) Crop losses to pests. J Agric Sci 144(01):31-43. doi:10.1017/S0021859605005708 
Pakeman RJ, Leps J, Kleyer M, Lavorel S, Garnier E (2009) Relative climatic, edaphic and management controls of plant functional trait signatures. J Veg Sci 20(1):148-159. doi:10.1111/j.1654-1103. 2009.05548.x

Petit S, Boursault A, Le Guilloux M, Munier-Jolain N, Reboud X (2011) Weeds in agricultural landscapes. A Rev Agron Sustain Dev 31(2):309-317. doi:10.1051/agro/2010020

Pierce S, Maxwell K, Griffiths H, Winter K (2001) Hydrophobic trichome layers and epicuticular wax powders in Bromeliaceae. Am J Bot 88:1371-1389

Rees M, Westoby M (1997) Game-theoretical evolution of seed mass in multi-species ecological models. Oikos 78(1):116-126

Reuss SA, Buhler DD, Gunsolus JL (2001) Effects of soil depth and aggregate size on weed seed distribution and viability in a silt loam soil. Appl Soil Ecol 16(3):209-217. doi:10.1016/S0929-1393(00) 00115-3

Roberts HA, Feast PM (1973) Changes in the numbers of viable weed seeds in soil under different regimes. Weed Res 13:298-303

Robinson RA, Sutherland WJ (2002) Post-war changes in arable farming and biodiversity in Great Britain. J Appl Ecol 39:157-176

Roger-Estrade J, Richard G, Caneill J, Boizard H, Coquet Y, Defossez P, Manichon H (2004) Morphological characterisation of soil structure in tilled fields: from a diagnosis method to the modelling of structural changes over time. Soil Tillage Res 79(1):33-49. doi:10.1016/j.still.2004.03.009

Roger-Estrade J, Richard G, Bertrand M, Darboux F, Défossez P (2006) La composante physique. In: L'agronomie aujourd'hui. Editions QUAE, Paris

Roger-Estrade J, Richard G, Dexter AR, Boizard H, De Tourdonnet S, Bertrand M, Caneill J (2009) Integration of soil structure variations with time and space into models for crop management. A Rev Agron Sustain Dev 29(1):135-142. doi:10.1051/agro:2008052

Ryan MR, Smith RG, Mirsky SB, Mortensen DA, Seidel R (2010) Management filters and species traits: weed community assembly in long-term organic and conventional systems. Weed Sci 58:265277

Salisbury EJ (1942) The reproductive capacity of plants. Georges Bell \& Sons, London

Sans FX, Massalles RM (1994) Life-history variation in the annual arable weed Diplotaxis erucoides (Cruciferae). Can J Bot 72:10 19

Schwinning S (1996) Decomposition analysis of competitive symmetry and size structure dynamics. Ann Bot 77:47-57

Sciama D, Augusto L, Dupouey J-L, Gonzalez M, Moares DomÃnguez Cn (2009) Floristic and ecological differences between recent and ancient forests growing on non-acidic soils. For Ecol Manag 258 (5):600-608. doi:10.1016/j.foreco.2009.04.027

Shipley B, Vile D, Garnier E (2006) From plant traits to plant communities: a statistical mechanistic approach to biodiversity. Science 314(5800):812-814

Smith RG (2006) Timing of tillage is an important filter on the assembly of weed communities. Weed Sci 54(4):705-712

Smith HG, Dänhardt J, Lindström A, Rundlöf M (2010) Consequences of organic farming and landscape heterogeneity for species richness and abundance of farmland birds. Oecologia 162(4):10711079

Sonnier G, Navas M-L, Fayolle A, Shipley B (2012) Quantifying trait selection driving community assembly: a test in herbaceous plant communities under contrasted land use regimes. Oikos 121(7):11031111. doi:10.1111/j.1600-0706.2011.19871.x

Sousa WP (1984) The role of disturbance in natural communities. Annu Rev Ecol Syst 15:353-391

Staniforth DW, Wiese AF (1985) Weed biology and its relationship to weed control in limited-tillage systems. In: Wiese AF (ed) Weed control in limited tillage systems. Monograph Series of the Weed Science Society of America, Champaign, pp 15-25
Stoate C, Boatman ND, Borralho RJ, Rio Carvalho C, de Snoo GR, Eden P (2001) Ecological impacts of arable intensification in Europe. J Env Manag 63:337-365

Storkey J (2005) Modelling assimilation rates of 14 temperate arable weed species as a function of the environment and leaf traits. Weed Res 45:361-370

Storkey J (2006) A functional group approach to the management of UK arable weeds to support biological diversity. Weed Res 46:513522

Storkey J, Westbury DB (2007) Managing arable weeds for biodiversity. Pest Manag Sci 63:517-523

Suding KN, Lavorel S, Chapin FS, Cornelissen JHC, Diaz S, Garnier E, Goldberg D, Hooper DU, Jackson ST, Navas ML (2008) Scaling environmental change through the community-level: a trait-based response-and-effect framework for plants. Glob Chang Biol 14(5):1125-1140. doi:10.1111/j.1365-2486.2008.01557.x

Sun S, Frelich LE (2011) Flowering phenology and height growth pattern are associated with maximum plant height, relative growth rate and stem tissue mass density in herbaceous grassland species. J Ecol 99(4):991-1000. doi:10.1111/j.1365-2745.2011.01830.x

Swanton CJ, Booth BD, Chandler K, Clements DR, Shrestha A (2006) Management in a modified no-tillage corn-soybean-wheat rotation influences weed population and community dynamics. Weed Sci 54(1):47-58. doi:10.1614/ws-05-013r1.1

Tilman D, Balzer C, Hill J, Befort BL (2011) Global food demand and the sustainable intensification of agriculture. Proc Natl Acad Sci 108(50):20260-20264. doi:10.1073/pnas.1116437108

Turnbull LA, Rees M, Crawley MJ (1999) Seed mass and the competition/colonization trade-off: a sowing experiment. J Ecol 87(5):899-912

Turnbull LA, Coomes D, Hector A, Rees M (2004) Seed mass and the competition/colonization trade-off: competitive interactions and spatial patterns in a guild of annual plants. $J$ Ecol 92(1):97-109

Ulber L, Steinmann HH, Klimek S, Isselstein J (2009) An on-farm approach to investigate the impact of diversified crop rotations on weed species richness and composition in winter wheat. Weed Res 49(5):534-543. doi:10.1111/j.1365-3180.2009.00722.x

Violle C, Navas ML, Vile D, Kazakou E, Fortunel C, Hummel I, Garnier E (2007) Let the concept of trait be functional! Oikos 116(5):882-892

Violle C, Castro H, Richarte J, Navas ML (2009a) Intraspecific seed trait variations and competition: passive or adaptive response? Funct Ecol 23(3):612-620. doi:10.1111/j.1365-2435.2009.01539.x

Violle C, Garnier E, Lecoeur J, Roumet C, Podeur C, Blanchard A, Navas ML (2009b) Competition, traits and resource depletion in plant communities. Oecologia 160(4):747-755

Violle C, Enquist BJ, McGill BJ, Jiang L, Albert CH, Hulshof C, Jung V, Messier J (2012) The return of the variance: intraspecific variability in community ecology. Trends Ecol Evol 27(4):244 252. doi:10.1016/j.tree.2011.11.014

Wanamarta G, Penner D (1989) Foliar penetration of herbicides. Weed Sci 4:215-231

Warwick SI, Thompson BK (1987) Differential response to competition in weedy biotypes of proso millet. Rev Can Bot 65(7):1403-1409. doi: $10.1139 / \mathrm{b} 87-194$

Weiher E, van der Werf A, Thompson K, Roderick M, Garnier E, Eriksson O (1999) Challenging Theophrastus: a common core list of plant traits for functional ecology. J Veg Sci 10(5):609-620

Weiher E, Freund D, Bunton T, Stefanski A, Lee T, Bentivenga S (2011) Advances, challenges and a developing synthesis of ecological community assembly theory. Phil Trans R Soc B-Biol Sci 366(1576):2403-2413. doi:10.1098/rstb.2011.0056

Weiner J (1986) How competition for light and nutrients affects size variability in Ipomoea tricolor populations. Ecology 67:1425-1427 
Weiner J (1988) The influence of competition on plant reproduction. In: Lovett Doust J, Lovett Doust L (eds) Plant reproductive ecology: patterns and strategies. Oxford University Press, New York, pp 228-245

Weiner J (1990) Asymmetric competition in plant populations. Trends Ecol Evol 5:360-364

Weiner J, Andersen SB, Wille WKM, Griepentrog HW, Olsen JM (2010) Evolutionary agroecology: the potential for cooperative, high density, weed-suppressing cereals. Evol Appl 3(5-6):473479. doi:10.1111/j.1752-4571.2010.00144.x

Westoby M (1998) A leaf-height-seed (LHS) plant ecology strategy scheme. Plant Soil 199:213-227

Westoby M, Falster DS, Moles AT, Vesk PA, Wright IJ (2002) Plant ecological strategies: some leading dimensions of variation between species. Annu Rev Ecol Syst 33:125-159

Wezel A, Bellon S, Dore T, Francis C, Vallod D, David C (2009) Agroecology as a science, a movement and a practice. A Rev Agron Sustain Dev 29(4):503-515. doi:10.1051/agro/2009004

White PS, Jentsch A (2001) The search for generality in studies of disturbance and ecosystem dynamics. In: Esser K, Lüttge U,
Kadereit JW, Beyschlag W (eds) Progress in botany, vol 62 . Springer, Berlin, pp 399-450

White PS, Pickett STA (1985) Natural disturbance and patch dynamics: an introduction. In: Pickett STA, White PS (eds) The ecology of natural disturbance and patch dynamics. Academic Press, New York, pp 3-13

Whittaker RH (1965) Dominance and diversity in land plant communities. Science 147:250-260

Wright IJ, Reich PB, Westoby M, Ackerly DD, Baruch Z, Bongers F (2004) The worldwide leaf economics spectrum. Nature 428:821827

Xiao S, Chen S-Y, Zhao L-Q, Wang G (2006) Density effects on plant height growth and inequality in sunflower populations. J Integr Plant Biol 48(5):513-519. doi:10.1111/j.1744-7909. 2006.00265.x

Zanin G, Otto S, Riello L, Borin M (1997) Ecological interpretation of weed flora dynamics under different tillage systems. Agric Ecosyst Environ 66(3):177-188. doi:10.1016/S01678809(97)00081-9 